\title{
EFFECT OF SULFUR FERTILIZATION ON THE SANITARY STATE OF PLANTS OF THE FAMILY BRASSICACEAE
}

\author{
Tomasz P. Kurowski ${ }^{1}$, Barbara Majchrzak ${ }^{1}$, Krzysztof Jankowski \\ ${ }^{1}$ Department of Phytopathology and Entomology, \\ ${ }^{2}$ Department of Agrotechnology and Crop Management \\ University of Warmia and Mazury, Prawocheńskiego 17, 10-722 Olsztyn, Poland. \\ e-mail: kurowski@uwm.edu.pl
}

Received: 24.09.2009

\begin{abstract}
The experiment was carried out in the years 2006-2008 in Bałcyny ( $\left.\mathrm{N}=53^{\circ} 35^{\prime} 49^{\prime \prime} ; \mathrm{E}=19^{\circ} 51^{\prime} 20^{\prime \prime}\right)$. The aim of this study was to determine the effect of sulfur fertilization on the sanitary state of spring oilseed rape, winter oilseed rape, white mustard and Chinese mustard as well as on the species composition of fungi colonizing their seeds. Sulfur fertilization had a beneficial effect on the health of Brassicaceae plants infested by Alternaria blight, grey mould, Sclerotinia stem rot, Phoma stem canker and Verticillium wilt, but it had a varying effect on the occurrence of powdery mildew. Alternaria alternata and Penicillium spp. were isolated most frequently from Brassicaceae seeds. In general, more fungi (including pathogenic to Brassicaceae) were isolated from the seeds of plants grown in non-sulfur fertilized plots. Pathogens occurred primarily on the seed surface, and their number decreased after surface disinfection of seeds.
\end{abstract}

Key words: spring oilseed rape; winter oilseed rape; white mustard; Chinese mustard, sulfur fertilization; diseases; fungi colonizing seeds

\section{INTRODUCTION}

The EU strategy to reduce the atmospheric emissions of sulfur dioxide has led to sulfur deficiency in soil, which has recently become a serious problem in Poland (P o d leśn a, 2002). Sulfur deficiency may reduce the utilization of other nutrients, in particular nitrogen, by plants, since nitrogen metabolism is closely related to sulfur metabolism ( $\mathrm{J}$ a $\mathrm{n} \mathrm{ze} \mathrm{n}$ and B e t t a n y, 1984). Therefore, sulfur deficit can affect both the yield and quality of crops. Sulfur affects taste, flavor and appearance as well as processing suitability and nutritional value of agricultural products. Sulfur content also influences yield and quality of oil obtained (Podleśna, 2005). Fertilization, especially sulfur fertilization, has a significant effect on glucosinolate content of the tissues of cruciferous plants $(\mathrm{K} \mathrm{a}$ chlicki, 1990; Oleszek, 1995). The products of glucosinolate hydrolysis show toxicity against pathogenic fungi, bacteria, viruses, insects and higher plants (O leszek, 1995; Majchrzak et al. 2001; Majchrzak et al. 2004).

The aim of the study was to determine the effect of sulfur fertilization on the sanitary state of spring oilseed rape, winter oilseed rape, white mustard and Chinese mustard as well as on species composition of the fungal communities colonizing seeds of the above Brassicaceae species.

\section{MATERIALS AND METHODS}

The experiment was carried out in the years 2006-2008 in trial plots located at the Production and Experimental Station in Bałcyny near Ostróda in Poland ( $\left.\mathrm{N}=53^{\circ} 35^{\prime} 49^{\prime \prime} ; \mathrm{E}=19^{\circ} 51^{\prime} 20^{\prime \prime}\right)$. A field experiment was performed in a randomized block design, in six replications. The experimental material comprised spring oilseed rape (Brassica napus var. arvensis f. апnиa) cv. Hunter, winter oilseed rape (B. napus var. arvensis f. biennis) cv. Californium, white mustard (Sinapis alba) cv. Borowska and Chinese mustard (B. juncea) cv. Małopolska. The experiment was established on typical grey-brown medium-silty podsolic soil of good wheat complex, developed from light loam. Brassicaceae plants were grown in accordance with the relevant cultivation and fertilization standards. Mineral NPK fertilizers were applied as follows $\left(\mathrm{kgha}^{-1}\right)$ : winter rapeseed - 240:70:220, spring rapeseed and white mustard - 100:40:120, Chinese mustard - 70:30:80. In sulfur-fertilized treatments, the following doses of $\mathrm{S}\left(\mathrm{kg} \mathrm{ha}^{-1}\right)$ were applied at the beginning 
of the growing season: winter rapeseed -60 , spring rapeseed and white mustard - 40, Chinese mustard -25 . Before sowing, rape seeds were dressed with Cruiser OSR 322 FS (thiamethoxam + metalaxyl-M + fludioxonil), and mustard seeds - with Zaprawa nasienna $T$ (thiram). Crops were not protected against pathogens with fungicides throughout the growing season.

The health status of 25 plants collected randomly from each plot was evaluated three times during the growing season, using a four-point scale of Hillstrand and A uld (1982). The evaluation results which pointed to the highest severity of diseases were considered in the analysis. The injury index was calculated according to McKinney's formula ( $\mathrm{E} \mathrm{a} \mathrm{c} \mathrm{i} \mathrm{-}$ c ow a, 1970).

Fungi were isolated from seeds of the investigated plants after harvest. Every year 100 seeds were randomly sampled in each treatment. Half of the seeds were disinfected for 30 seconds in 50\% ethyl alcohol and for another 30 seconds in $0.1 \%$ sodium hypochlorite. The seeds were rinsed three times with sterile water, then dried on sterile filter paper and placed in Petri dishes on potato-glucose agar. The remaining seeds were rinsed with sterile water, and the further procedure was the same as for disinfected seeds. The colonies that developed were transferred onto potato-glucose agar slants, and the fungi were identified to species using available keys, following spore formation.

\section{RESULTS}

Powdery mildew occurred on spring oilseed rape leaves, and the symptoms of Alternaria blight were observed on siliques in all years of the study, however, grey mould occurred on siliques only in 2006 (Table 1a). The severity of diseases was dependent on weather conditions. The highest infection rate was noted in 2007, and it was lower in the sulfur-fertilized plots. Also in 2006, the incidence of powdery mildew and grey mould was lower in the sulfur-fertilized plots. Only in 2008 the severity of powdery mildew and Alternaria blight was higher in the sulfur-fertilized plots than in the control treatments.

The symptoms of Alternaria blight were noted on siliques of winter oilseed rape over the entire experimental period. The other diseases occurred in one year only - grey mould and Verticillium wilt in 2006, Sclerotinia stem root and Phoma stem canker in 2008 (Table 1b). In all cases, the sanitary state of winter oilseed rape was positively affected by sulfur fertilization.

The symptoms of Alternaria blight were observed on both the leaves and siliques of white mustard (Table 1c). The highest infection rate was noted in 2007. Again, sulfur fertilization had a beneficial effect on the health status of plants.
Powdery mildew occurred on Chinese mustard leaves, while siliques were attacked by Alternaria blight in all years of the study (Table 1d). Sulfur fertilization had varied effects on the health status of plants. In 2006 the effect of sulfur fertilization was non-significant with respect to both diseases. In 2007 sulfur fertilization exerted a beneficial influence, and in 2008 the plots fertilized with sulfur were characterized by higher severity of powdery mildew and lower severity of Alternaria blight on siliques.

A total of 407 fungal cultures representing 11 taxa were isolated from spring rape seeds (Table 2a), including 179 from sulfur-fertilized plants and 228 from non-fertilized plants. Seed disinfection contributed to a decrease in the number of fungal colonies - 193 colonies were isolated from disinfected seeds and 214 from non-disinfected seeds. The predominant species on spring rape seeds was Alternaria alternata, pathogenic to Brassicaceae ( $44.7 \%$ of isolates from the seeds of sulfur-fertilized plants and $53.5 \%$ from the seeds of non-fertilized plants). Fungi of the genus Penicillium (18.4\% and $21.1 \%$ respectively) and Cladosporium cladosporioides ( $24.6 \%$ and $10.5 \%$ respectively) also occurred in great abundance. Other pathogens of the Brassicaceae, isolated in the study, were Alternaria brassicae, Phoma lingam, Fusarium oxysporum and F. sporotrichioides. All of them dominated on seeds of the plants that were not fertilized with sulfur. Disinfection reduced the percentage share of potential pathogens of Brassicaceae among the obtained isolates. The only species whose proportion increased following seed disinfection was Cladosporium cladosporioides.

A total of 249 fungal colonies belonging to 15 taxa were isolated from winter rape seeds (Table 2b), including 98 from the seeds of sulfur-fertilized plants and 151 from the seeds of non-fertilized plants. Seed disinfection considerably decreased the number of fungal colonies - 95 colonies were isolated from disinfected seeds and 154 from non-disinfected seeds. The predominant species on winter rape seeds was A. alternata $50.0 \%$ of isolates from the seeds of sulfur-fertilized plants and $55.0 \%$ from the seeds of nonfertilized plants). Fungi of the genus Penicillium were also abundant (23.5\% and $20.5 \%$, respectively). Other pathogens of the Brassicaceae were A. brassicae, $F$. oxysporum, $F$. poae and F. tricinctum. They dominated on seeds of the plants that were not fertilized with sulfur. Disinfection reduced the percentage share of potential pathogens of Brassicaceae among the obtained isolates.

A total of 524 fungal colonies representing 12 taxa were isolated from white mustard seeds (Table 2c), including 250 from sulfur-fertilized plants and 274 from non-fertilized plants. Seed disinfection contributed to a decrease in the number of fungal colonies 
- 253 colonies were isolated from disinfected seeds and 271 from non-disinfected seeds. Fungi of the genus Penicillium dominated among the obtained isolates $58.0 \%$ of isolates from the seeds of sulfur-fertilized plants and $49.3 \%$ from the seeds of non-fertilized plants). A. alternata also occurred in great abundance (34.8\% and $39.0 \%$, respectively). Other pathogens of the Brassicaceae were A. brassicae, F. oxysporum, $F$. equiseti and Microdochium nivale. They dominated on seeds of the plants that were fertilized with sulfur. Disinfection reduced the percentage share of potential pathogens of Brassicaceae among the obtained isolates, and Fusarium spp. were isolated only from nondisinfected seeds.

Table 1

Intensity of diseases on plants of the family Brassicaceae (injury index in \%)

a/ spring oilseed rape

\begin{tabular}{|c|c|c|c|c|c|}
\hline \multirow{2}{*}{ Disease (Pathogen) } & \multirow{2}{*}{ Plant part } & \multirow{2}{*}{ Year } & \multicolumn{2}{|c|}{ Fertilization } & \multirow{2}{*}{$\begin{array}{c}\mathrm{LSD} \\
(\mathrm{p}=0.05)\end{array}$} \\
\hline & & & with sulfur & without sulfur & \\
\hline \multirow{3}{*}{$\begin{array}{l}\text { Powdery mildew } \\
\text { (Erysiphe cruciferarum) }\end{array}$} & \multirow{3}{*}{ leaves } & 2006 & 38.7 & 40.7 & 1.41 \\
\hline & & 2007 & 68.0 & 79.6 & 1.06 \\
\hline & & 2008 & 24.6 & 13.9 & 1.56 \\
\hline \multirow{3}{*}{$\begin{array}{l}\text { Alternaria blight } \\
\text { (Alternaria alternata et al.) }\end{array}$} & \multirow{3}{*}{ siliques } & 2006 & 6.9 & 5.4 & n.s. \\
\hline & & 2007 & 68.4 & 70.6 & 1.01 \\
\hline & & 2008 & 17.3 & 9.7 & 1.70 \\
\hline $\begin{array}{l}\text { Grey mould } \\
\text { (Botrytis cinerea) }\end{array}$ & siliques & 2006 & 34.0 & 37.0 & 2.33 \\
\hline \multicolumn{6}{|l|}{$\mathrm{b} /$ winter oilseed rape } \\
\hline \multirow{3}{*}{$\begin{array}{l}\text { Alternaria blight } \\
\text { (Alternaria alternata et al.) }\end{array}$} & \multirow{3}{*}{ siliques } & 2006 & 13.9 & 17.1 & 1.57 \\
\hline & & 2007 & 5.9 & 8.3 & 0.75 \\
\hline & & 2008 & 8.0 & 14.7 & 1.37 \\
\hline $\begin{array}{l}\text { Grey mould } \\
\text { (Botrytis cinerea) }\end{array}$ & siliques & 2006 & 6.9 & 8.9 & 0.99 \\
\hline $\begin{array}{l}\text { Verticillium wilt } \\
\text { (Verticilium dahlie) }\end{array}$ & leaves & 2006 & 4.9 & 6.1 & 0.78 \\
\hline $\begin{array}{l}\text { Phoma stem canker } \\
(\text { Phoma lingam })\end{array}$ & stems & 2008 & 13.2 & 22.3 & 2.37 \\
\hline $\begin{array}{l}\text { Sclerotinia stem root } \\
\text { (Sclerotinia sclerotiorum) }\end{array}$ & stems & 2008 & 13.1 & 18.6 & 1.68 \\
\hline \multicolumn{6}{|l|}{ c/ white mustard } \\
\hline \multirow{3}{*}{$\begin{array}{l}\text { Alternaria blight } \\
\text { (Alternaria alternata et al.) }\end{array}$} & \multirow{3}{*}{ leaves } & 2006 & 7.0 & 7.1 & n.s. \\
\hline & & 2007 & 57.7 & 69.4 & 1.01 \\
\hline & & 2008 & 3.1 & 7.7 & 1.14 \\
\hline \multirow{2}{*}{$\begin{array}{l}\text { Alternaria blight } \\
\text { (Alternaria alternata et al.) }\end{array}$} & \multirow{2}{*}{ siliques } & 2007 & 6.7 & 18.9 & 0.82 \\
\hline & & 2008 & 0.3 & 1.7 & 0.50 \\
\hline \multicolumn{6}{|l|}{$\mathrm{d} /$ Chinese mustard } \\
\hline \multirow{3}{*}{$\begin{array}{l}\text { Powdery mildew } \\
\text { (Erysiphe cruciferarum) }\end{array}$} & \multirow{3}{*}{ leaves } & 2006 & 77.2 & 73.9 & n.s. \\
\hline & & 2007 & 74.3 & 88.7 & 1.07 \\
\hline & & 2008 & 99.4 & 89.7 & 1.28 \\
\hline \multirow{3}{*}{$\begin{array}{l}\text { Alternaria blight } \\
\text { (Alternaria alternata et al.) }\end{array}$} & \multirow{3}{*}{ siliques } & 2006 & 42.6 & 41.0 & n.s. \\
\hline & & 2007 & 53.4 & 81.3 & 0.94 \\
\hline & & 2008 & 5.2 & 5.8 & 0.47 \\
\hline
\end{tabular}

n.s. - not significant differences 
Table 2

Fungi isolated from seeds of Brassicaceae plants

a/ spring oilseed rape

\begin{tabular}{|c|c|c|c|c|c|c|}
\hline \multirow{3}{*}{ Species of fungus } & \multicolumn{4}{|c|}{ Fertilization } & \multirow{2}{*}{\multicolumn{2}{|c|}{ Sum }} \\
\hline & \multicolumn{2}{|c|}{ with sulfur } & \multicolumn{2}{|c|}{ without sulfur } & & \\
\hline & $\mathrm{d}$ & nd & $\mathrm{d}$ & nd & $\mathrm{d}$ & nd \\
\hline Alternaria alternata (Fr.) Keissler & 31 & 49 & 60 & 62 & 91 & 111 \\
\hline Alternaria brassicae (Berk.) Sacc. & & 2 & 4 & 6 & 4 & 8 \\
\hline Aspergillus niger van Tieghem & 8 & & & & 8 & \\
\hline Cladosporium cladosporioides (Fresen.) de Vries & 28 & 16 & 9 & 15 & 37 & 31 \\
\hline Epicoccum purpurascens Ehrenb. ex Schlecht. & 1 & & & 2 & 1 & 2 \\
\hline Fusarium oxysporum Schlecht. & & 2 & 3 & 2 & 3 & 4 \\
\hline Fusarium sporotrichioides Sherb. & & & 1 & 3 & 1 & 3 \\
\hline Mucor circinelloides van Tieghem & 1 & & & & 1 & \\
\hline Penicillium spp. & 11 & 22 & 25 & 23 & 36 & 45 \\
\hline Phoma lingam (Tode) Desm. & & & & 3 & & 3 \\
\hline Non-sporulating fungi & 5 & 3 & 6 & 4 & 11 & 7 \\
\hline Total & 85 & 94 & 108 & 120 & 193 & 214 \\
\hline
\end{tabular}

b/ winter oilseed rape

\begin{tabular}{|c|c|c|c|c|c|c|}
\hline \multirow{3}{*}{ Species of fungus } & \multicolumn{4}{|c|}{ Fertilization } & \multirow{2}{*}{\multicolumn{2}{|c|}{ Sum }} \\
\hline & \multicolumn{2}{|c|}{ with sulfur } & \multicolumn{2}{|c|}{ without sulfur } & & \\
\hline & $\mathrm{d}$ & nd & $\mathrm{d}$ & nd & d & nd \\
\hline Acremonium murorum W. Gams & & & 1 & & 1 & \\
\hline Acremonium strictum W. Gams & 6 & 1 & & 1 & 6 & 2 \\
\hline Alternaria alternata (Fr.) Keissler & 16 & 33 & 29 & 54 & 45 & 87 \\
\hline Alternaria brassicae (Berk.) Sacc. & 1 & 3 & 4 & 4 & 5 & 7 \\
\hline Aspergillus niger van Tieghem & 1 & & & & 1 & \\
\hline Cladosporium cladosporioides (Fresen.) de Vries & 1 & 4 & 2 & 1 & 3 & 5 \\
\hline Epicoccum purpurascens Ehrenb. ex Schlecht. & & 1 & 2 & 1 & 2 & 2 \\
\hline Fusarium oxysporum Schlecht. & & 1 & 1 & 2 & 1 & 3 \\
\hline Fusarium poae (Peck.) Wollenw. & & & & 1 & & 1 \\
\hline Fusarium tricinctum (Corda) Sacc. & 1 & & & & 1 & \\
\hline Mucor hiemalis Wehmer & & & & 2 & & 2 \\
\hline Penicillium spp. & 5 & 18 & 14 & 17 & 19 & 35 \\
\hline Non-sporulating fungi & 4 & 2 & 7 & 7 & 11 & 9 \\
\hline Yeast-like fungi & & & & 1 & & 1 \\
\hline Total & 35 & 63 & 60 & 91 & 95 & 154 \\
\hline
\end{tabular}


Table 2 cont.

c/ white mustard

\begin{tabular}{|c|c|c|c|c|c|c|}
\hline \multirow{3}{*}{ Species of fungus } & \multicolumn{4}{|c|}{ Fertilization } & \multirow{2}{*}{\multicolumn{2}{|c|}{ Sum }} \\
\hline & \multicolumn{2}{|c|}{ with sulfur } & \multicolumn{2}{|c|}{ without sulfur } & & \\
\hline & $\mathrm{d}$ & nd & $\mathrm{d}$ & nd & $\mathrm{d}$ & nd \\
\hline Alternaria alternata (Fr.) Keissler & 47 & 40 & 54 & 53 & 121 & 93 \\
\hline Alternaria brassicae (Berk.) Sacc. & 2 & 1 & 6 & 9 & 8 & 10 \\
\hline Aspergillus sp. & 2 & & & & 2 & \\
\hline Cladosporium cladosporioides (Fresen.) de Vries & 1 & & & & 1 & \\
\hline Epicoccum purpurascens Ehrenb. ex Schlecht. & & & 1 & & 1 & \\
\hline Fusarium equiseti (Corda) Sacc. & & 5 & & 3 & & 8 \\
\hline Fusarium oxysporum Schlecht. & & 3 & & & & 3 \\
\hline Microdochium nivale (Fr.) Samuels et Hallett & & & & 1 & & 1 \\
\hline Penicillium spp. & 67 & 78 & 71 & 64 & 138 & 162 \\
\hline Rhizopus nigricans Ehr. & & 4 & & 6 & & 10 \\
\hline Non-sporulating fungi & & & 2 & & 2 & \\
\hline Yeast-like fungi & & & & 4 & & 4 \\
\hline Total & 119 & 131 & 134 & 140 & 273 & 291 \\
\hline
\end{tabular}

\begin{tabular}{|c|c|c|c|c|c|c|}
\hline \multirow{3}{*}{ Species of fungus } & \multicolumn{4}{|c|}{ Fertilization } & \multirow{2}{*}{\multicolumn{2}{|c|}{ Sum }} \\
\hline & \multicolumn{2}{|c|}{ with sulfur } & \multicolumn{2}{|c|}{ without sulfur } & & \\
\hline & $\mathrm{d}$ & nd & $\mathrm{d}$ & nd & $\mathrm{d}$ & nd \\
\hline Alternaria alternata (Fr.) Keissler & 57 & 59 & 63 & 70 & 120 & 129 \\
\hline Alternaria brassicae (Berk.) Sacc. & 3 & 1 & 2 & 7 & 5 & 8 \\
\hline Cladosporium cladosporioides (Fresen.) de Vries & & & & 3 & & 3 \\
\hline Epicoccum purpurascens Ehrenb. ex Schlecht. & & 3 & 1 & 2 & 1 & 5 \\
\hline Fusarium oxysporum Schlecht. & & 1 & & 5 & & 6 \\
\hline Monodictys levis (Wiltshire) Hughes & & & & 1 & & 1 \\
\hline Mucor circinelloides van Tieghem & 5 & 10 & & & 5 & 10 \\
\hline Mucor hiemalis Wehmer & & & & 3 & & 3 \\
\hline Penicillium spp. & 24 & 19 & 29 & 28 & 53 & 47 \\
\hline Phoma lingam (Tode) Desm. & & & 2 & & 2 & \\
\hline Rhizopus nigricans Ehr. & & 5 & & 2 & & 7 \\
\hline Non-sporulating fungi & 2 & & 4 & 1 & 6 & 1 \\
\hline Yeast-like fungi & & 1 & 4 & & 4 & 1 \\
\hline Total & 91 & 99 & 105 & 122 & 196 & 221 \\
\hline
\end{tabular}

$\mathrm{d}$ - disinfected seeds

nd - non-disinfected seeds 
A total of 417 fungal colonies belonging to 13 taxa were isolated from Chinese mustard seeds (Table 2d), including 190 from sulfur-fertilized plants and 227 from non-fertilized plants. Seed disinfection decreased the number of fungal colonies - 196 colonies were isolated from disinfected seeds and 221 from non-disinfected seeds. The predominant species on Chinese mustard seeds was A. alternata $(61.1 \%$ of isolates from the seeds of sulfur-fertilized plants and $58.6 \%$ from the seeds of non-fertilized plants). Fungi of the genus Penicillium were also abundant $(22.6 \%$ and $25.1 \%$, respectively). Other pathogens of the Brassicaceae were A. brassicae, $F$. oxysporum and Phoma lingam which occurred in higher abundance on seeds of the plants that were not fertilized with sulfur.

\section{DISCUSSION}

The symptoms of Alternaria blight were observed throughout the entire experimental period on all four species of Brassicaceae. The disease incidence was determined primarily by weather conditions during the growing season. The year 2007, in which June was dry and total precipitation in July was twice higher than the long-term average, provided the most favorable conditions for the development of Alternaria blight on spring crucifers. Winter rapeseed, which reaches maturity at the end of June and at the beginning of July, was not significantly infected in 2007. The considerable effect of weather conditions on the severity of diseases attacking cruciferous plants, including the most severe one - Alternaria blight, has been described by numerous authors (P l a c h ka, 1996 ; J ę d r y c z ka et al. 2002; Kurowski and Budzyński, 2003; Kurowski and Jankowski, 2003).

In each year of the study, the disease infection rates were affected by sulfur fertilization. The application of sulfur fertilizers was found to alleviate the severity of infection caused by Alternaria spp. on winter rapeseed, white mustard and Chinese mustard. As regards spring rapeseed, the effect of sulfur fertilization varied throughout the experimental period. Powdery mildew, which occurred in all years of the study but only on spring rapeseed and Chinese mustard, attacked to a higher degree non-fertilized plants during the first two years, and fertilized plants in the last year. The symptoms of other diseases, i.e. grey mould, Sclerotinia stem rot, Phoma stem canker and Verticillium wilt, were noted in one year only and were stronger in the non-fertilized treatments. It may be concluded that in this experiment sulfur fertilization had a beneficial influence on the health status of Brassicaceae plants, and the best results were reported for winter rapeseed fertilized with the highest doses of nitrogen and sulfur.

Brassicaceae have a high sulfur demand. Sulfur availability plays an important role in plant protection against stress factors such as frost and drought. The frost resistance of crops is dependent on carbohydrate content and protein hydration, determined by sulfurcontaining compounds - sulfhydryls (L e vitt et al. 1961). According to Podleśn a et al. (2003), these compounds are also capable of protecting plants against drought. Plants living under stress conditions are more exposed to attack by various pathogens, in particular incidental pathogens, including those noted in the present study (except for Erysiphe cruciferarum). Cruciferous plants produce glucosinolates which contain sulfur and contribute to protection against pathogens. The products of glucosinolate hydrolysis inhibit in vitro growth of Phoma lingam and Sclerotinia sclerotiorum ( $\mathrm{S} \mathrm{ch} \mathrm{nug}$ and C e y n ow a, 1990). A lower incidence of fungal diseases on the Brassicaceae fertilized with sulfur was also demonstrated by $\mathrm{P}$ a $\nmid$ o s z (1995), J ę d r y c z k a et al. (2002) and S a d o w s ki et al. (2002). The protective effect of sulfur was reported with respect to, among others, Alternaria blight, powdery mildew, downy mildew, light leaf spot and Phoma stem canker.

Alternaria alternata was isolated most frequently from the seeds of Brassicaceae plants, followed by Penicillium spp. Other fungal species occurred sporadically. Apart from A. alternata, the following pathogens were also isolated from Brassicaceae seeds: A. brassicae, Fusarium equiseti, F. oxysporum, F. sporotrichioides and $F$. tricinctum. Alternaria alternata is a typical cosmopolitan species which dominates among the isolates obtained from many plant species. It is considered potentially dangerous due to the production of toxins (Chełkowski and Grabarki ewiczS zczęs na, 1991). Fungi of the genus Penicillium also occur commonly and are characterized by strong enzymatic properties. Alternaria alternata and members of the genus Penicillium are considered by many authors to infest most frequently cruciferous seeds (Richardson, 1996; Majchrzak et al. 2002).

In general, more fungi (including those pathogenic to Brassicaceae) were isolated from the seeds of plants grown in the control plots - without sulfur fertilization. The application of sulfur fertilizers caused substantial reductions in the abundance of fungi colonizing Brassicaceae seeds. The greatest differences were observed with regard to winter rapeseed. Only C. cladosporioides and, to a much lower degree, Penicillium spp., found better conditions for development on seeds of the sulfur-fertilized plants $(7.0 \%$ and $3.4 \%$, and $34.0 \%$ and $30.8 \%$ of all isolates from the Brassicaceae, respectively). These results are consistent with field trial findings which showed that sulfur-fertilized plants were healthier and that glucosinolates, whose concentration is highest in seeds, inhibited the growth of many fungi on seeds ( $\mathrm{S} \mathrm{chnug}$ and Ce ynowa, 1990; Wielebski and W ój towicz, 2003). 
The total number of fungal colonies isolated from disinfected seeds was lower, as compared with non-disinfected seeds. Pathogens occurred primarily on the seed surface, and their numbers decreased after surface disinfection of seeds. Similar results were reported by M u si a 1 (1996) for grass seeds, and by M a j chrzak et al. (2002) for Brassicaceae seeds.

\section{CONCLUSIONS}

1. The most common disease, whose symptoms were observed most frequently on the aboveground parts of Brassicaceae, was Alternaria blight. Infection severity was determined primarily by weather conditions towards the end of the growing season.

2. Sulfur fertilization had a beneficial effect on the health status of Brassicaceae.

3. Alternaria alternata and fungi of the genus Penicillium dominated on the seeds of cruciferous plants.

4. The application of sulfur fertilizers substantially reduced the abundance of fungi, including pathogens, colonizing Brassicaceae seeds.

5. Winter oilseed rape fertilized with high doses of nitrogen showed the strongest response to sulfur fertilization.

\section{Acknowledgments}

This study was partially financed by research funds for the years 2007-2010 under a research project N310 031 32/1670 of the Ministry of Science and Higher Education in Poland.

\section{REFERENCES}

Chełkowski J., Grabarkiewicz-Szczęsna J., 1991. Alternaria and their metabolites in cereal grain. In: Cereal Grain - Mycotoxins, Fungi and Quality in Drying and Storage, Elsevier, Development in Science 26, Chapter, 4: 67-76.

Hillstrand D.S., Auld D.J., 1982. Comparative evaluation of four techniques for screening winter peas for resistance to Phoma medicaginis var. pinodella. Crop Sci. 22 (2): 282-287.

Janzen H.H., Bettany J.R., 1984. Sulfur nutrition of rapeseed: I. Influence of fertilizer nitrogen and sulfur rates. Soil Sci. Soc. Am. J. 48: 100-107.

Jędryczka M., Podleśna A., Lewartowska E., 2002. Wpływ nawożenia azotem i siarką na zdrowotność roślin rzepaku ozimego. / Effect of fertilization with nitrogen and sulphur on healthiness of winter oilseed rape plants. Pam. Puławski, 130/I: 329-337.

Kachlicki P., 1990. Glukozynolany i inne związki niskocząsteczkowe specyficzne dla rodzaju Brassica. Występowanie, właściwości i rola w metabolizmie rośliny. / Glucosinolanes and other low-molecular compounds specific for genus Brassica. Their occurrence, characteristics and role in plant metabolism. Rośl. Oleiste, XI: 65-74.

Kurowski T.P., Budzyński W., 2003. Wpływ zróżnicowanego nawożenia azotem i ochrony przed szkodnikami na zdrowotność rzepaku jarego. / Influence of differentiated fertilization and insecticide protection on sanitary state of spring oilseed rape. Rośl. Oleiste, XXIV (2): 465-473.

Ku rowsk i T.P., Jankowski K., 2003. Wpływ nawożenia na zdrowotność gorczycy białej i sarepskiej. / Influence of fertilization on health status of white and Indian mustard. Rośl. Oleiste, XXIV (2): 475-486.

Levitt J., Sullivan CH.Y., Johansson N-O., Pettit R.M., 1961. Sulfhydryls - a new factor in frost resistance. I. Changes in $\mathrm{SH}$ content during frost hardening. Plant Physiol. 36: 611-616.

Łacic owa B., 1970. Badanie szczepów Helminthosporium sorokinianum (H. sativum) oraz odporności odmian jęczmienia jarego na ten czynnik chorobotwórczy. I Investigation on Helminthosporium sorokinianum $(H$. sativum) strains and on the resistance of spring barley varietes to this pathogenic factor. Acta Mycol. 6 (2): 187-248.

Majchrzak B., Wachowska U., Chodorowski B., 2001. Wpływ mieszaniny glukozynolanów na wzrost kolonii grzybów w warunkach in vitro. / Influence of glucosinolate mixture on growth of fungi in vitro. Zesz. Probl. Post. Nauk Roln. 478: 249-255.

Majchrzak B., Kurowski T.P., Karpińska Z., 2002. Zdrowotność jarych roślin krzyżowych a grzyby zasiedlające ich nasiona. / The health condition of spring oilseed crops in relation to the fungi colonizing their seeds. Acta Agrobot. 55 (1): 199-210.

Majchrzak B., Ciska E., Wa leryś Z., 2004. Glukozynolany ekstrahowane z nasion jarych roślin krzyżowych i ich wpływ na wzrost grzybów patogenicznych. / Glucosinolates extracted from spring cruciferae seeds and their influence on the growth of pathogenic fungi. Progress Plant Prot./ Postępy Ochr. Rośl. 44 (2): 933936.

Musiał B., 1996. Niektóre choroby pochodzenia grzybowego na nasionach traw. / Some fungal diseases on the seeds of grasses. Biul. IHAR, 199: 149-155.

Oleszek W., 1995. Glukozynolany - występowanie i znaczenie ekologiczne. / Glucosinolates - their occurrence and ecological significance. Wiad. Botan. 39 (1/2): 49-58.

Pałos z T., 1995. Siarka a problemy fitosanitarne w uprawie rzepaku ozimego. / Sulphur in context of phytosanitary problems in winter oilseed rape cultivation. Ochr. Rośl. 12: 5-6.

Plachka E., 1996. Występowanie chorób grzybowych na rzepaku ozimym w Republice Czeskiej w 1995 roku. / The occurrence of fungal diseases on winter oilseed rape in the Czech Republic in 1995. Rośl. Oleiste, XVII (1): 171-178. 
Podleśna A., 2002. Air pollution by sulfur dioxide in Poland - impact on agriculture. Phyton, Ann. Rei Botanicae, 42 (3): 157-164.

Podleśna A., Cacak-Pietrzak G., Sowiński M., 2003. Reakcja pszenicy ozimej na nawożenie siarką w doświadczeniu polowym. / The response of winter wheat sulfur fertilization in a field experiment. Nawozy $\mathrm{i}$ Nawożenie, 4 (17): 169-179.

Podleśna A., 2005. Nawożenie siarką jako czynnik kształtujący metabolizm roślin uprawnych i jakość płodów rolnych. / Sulfur fertilization as a factor affecting crop metabolism and quality of agricultural products. Pam. Puławski, 139: 161-174.

Richards on M. J., 1996. Seed mycology. Mycol. Res. 100 (4): 385-392.

Sadowski C., Baturo A., Lenc L., Trzciński J., 2002. Występowanie mączniaka rzekomego (Peronospora parasitica/ Pers. ex Fr./Fr.) i mączniaka prawdziwego (Erysiphe cruciferarum Opiz ex L. Junell) na rzepaku jarym odmiany Star przy zróżnicowanym nawożeniu azotem i siarką. / Downy mildew (P. parasitica) and powdery mildew (E. cruciferarum) occurrence on spring oilseed rape cv. Star depending on differentiated fertilisation with nitrogen and sulphur. Rośl. Oleiste, XXIII (2): 391-408

Schnug E., Ceynowa J., 1990. Phytopathological aspects of glucosinolates in oilseed rape. J. Agron. Crop Sci. 165: 319-328

Wielebski F., Wójtowicz M., 2003. Wpływ wiosennego nawożenia siarką na plon i zawartość glukozynolanów w nasionach odmian mieszańcowych złożonych rzepaku ozimego. / Effect of spring sulphur fertilization on yield and glucosinolate content in seeds of winter oilseed rape composite hybrids. Rośl. Oleiste XXIV(1): 109-120.

\section{Wpływ nawożenia siarką na zdrowotność roślin kapustnych}

Streszczenie

Badania prowadzono w latach 2006-2008 na poletkach doświadczalnych zlokalizowanych w Zakładzie Produkcyjno-Doświadczalnym w Bałcynach k. Ostródy ( $\left.\mathrm{N}=53^{\circ} 35^{\prime} 49^{\prime \prime} ; \mathrm{E}=19^{\circ} 51^{\prime} 20^{\prime \prime}\right)$. Oceniano wpływ nawożenia siarką na zdrowotność rzepaku jarego, rzepaku ozimego, gorczycy białej i gorczycy sarepskiej oraz na skład gatunkowy grzybów zasiedlających nasiona tych roślin kapustnych.

Generalnie nawożenie siarką wpłynęło korzystnie na zdrowotność roślin kapustnych zmniejszając nasilenie czerni krzyżowych, szarej pleśni, zgnilizny twardzikowej, suchej plamistości i werticiliozy, natomiast wpływ nawożenia siarką na rozwój mączniaka prawdziwego był niejednoznaczny i zależał przede wszystkim od przebiegu pogody.

$\mathrm{Z}$ nasion roślin kapustnych izolowano głównie Alternaria alternata, a w mniejszym nasileniu grzyby rodzaju Penicillium. $\mathrm{Z}$ nasion roślin nie nawożonych siarką izolowano więcej grzybów, w tym patogenicznych dla roślin kapustnych. Patogeny występowały głównie na powierzchni nasion, a ich liczba malała po powierzchniowym odkażeniu nasion. 